\title{
WOMEN AND AUSTERITY IN ITALY
}

\section{Maria Luigia Segnana and Paola Villa}

Department of Economics and Management, University of Trento, Italy

\begin{abstract}
The paper considers how the severe and long downturn in the first phase of the crisis, followed by fiscal consolidation (austerity policies) in its second phase, have heavily impacted on women and men in Italy. It argues that the effects are considerably different - in terms of job loss, income loss, impact on jobs quality and unpaid work - because of the gendered nature of the family-employment system and the characteristics of the Italian social model.
\end{abstract}

Keywords: recession, gender, employment, labour market, family-employment system, Italy.

\section{Resumo}

Mulheres e austeridade em Itália

O documento analisa como a crise grave e longa na sua primeira fase, seguida de consolidação fiscal (políticas de austeridade) na segunda fase, teve forte impacto em mulheres e homens na Itália. Argumenta-se que os efeitos são muito diferentes - em termos de perda de emprego, perda de rendimento, qualidade do emprego e trabalho não remunerado - por causa das normas de género na formação do sistema família-trabalho e as características do modelo social na Italia.

Palavras-chave: recessão, género, emprego, mercado de trabalho, sistema de família-emprego, Itália.

\section{Resumen}

\section{Mujeres y austeridad en Italia}

El documento considera cómo la recesión severa y larga en la primera fase de la crisis, seguida de la consolidación fiscal (políticas de austeridad) en la segunda fase de la crisis, en gran medida han impactado en las mujeres y los hombres en Italia. Se argumenta que los efectos son muy diferentes - en términos de pérdida de empleo, pérdida de ingresos, el impacto en la calidad del empleo y el trabajo no remunerado - a causa de la naturaleza de género del sistema de la familia-empleo y las características del modelo social italiano.

Palabras-clave: recesión, género, empleo, mercado de trabajo, sistema de familiaempleo, Itália. 


\section{Introduction}

This paper considers the impact of austerity policies on women and men in Italy in terms of job loss, income loss, jobs quality and unpaid work. It does so along two dimensions: first, the family employment system, which captures the specific weaknesses of a welfare model rooted in long-standing imbalances; second, the decisive shifts to austerity policies that have prioritised fiscal consolidation over employment and social inclusion.

The results show the gendered nature of the family-employment system (sect. 2), the main features of austerity policies (sect. 3), and the different impacts of these policies on women and men (sect. 4). They highlight, on the one hand, that the Italian family-employment system has now locked young women in a new intergenerational solidarity trap unable to absorb the disruptive effects of the crisis; on the other hand, that the crisis's main effect is on the quality of female jobs, exacerbating the structural weaknesses of the Italian labour market. Both are examples of exclusive rather than inclusive growth, for which Italy is loosing ground in a comparative perspective.

\section{The Italian case}

The global financial crisis has focused attention on the role that national governments should and do play in an internationally integrated economic system. The issue is rooted in the debate on globalization. It is sometimes called the paradox of globalization' (Rodrik, 2011) because it may undermine long-standing social bargains reflected in domestic regulations; but it is also rooted in the European debate on the unfulfilled promises of EU reactions to the global crisis (i.e. austerity).

Globalization can be disruptive by its very nature: it rearranges where and how work is done and where and how profits are made. Processes that are disruptive destabilise and create pools of winners and losers. And this requires government policies to shelter citizens from risks and new vulnerabilities more important in countries where international market access enhances opportunities to trade but also exposes workers to more frequent and intense shocks.

This global perspective requires deeper evaluation at macro (Seguino, 2012) and micro level, as well as at European and national level: austerity policies in Europe have deeply affected the size and scope of different European social welfare models, leading to a long term shift in the trajectory of gender relations in Europe (Rubery, 2015; Perrons, 2015; Karamessini and Rubery, eds. 2014).

In the case of Italy, the external pressures have been reinforced by the internal austerity packages ${ }^{1}$ that have prioritised fiscal consolidation over employment

On the effects of fiscal consolidation and the unsuccess of Italian policies to achieve growth see Simonazzi (2015b). 
and social inclusion. As a result of the continuous downturn, Italy's GDP has reverted to the level of $2000,9 \%$ below the level of 2008, and total employment has contracted substantially. Compared with the peak in 2008, the decrease amounts to 1.1 million jobs (Banca d'Italia, 2014: 79). The severe and prolonged downturn has heavily impacted on women and men, though the effects are very different in terms of job loss, income loss, and impact on jobs quality - because of the gendered nature of the family-employment system and the familistic welfare model. Italy is certainly an example not only of the sluggish economic recovery and high structural unemployment but also of the decreasing size and scope of the welfare state, with detrimental effects on the difficult path towards gender equality.

\section{Family-employment system}

The Italian labour market is characterized by long-standing imbalances which include low female participation rates, high youth unemployment rates and a marked Centre-North vs. South divide. These imbalances are framed within an employment regime characterised by high rates of self-employment, large shares of people employed in small firms, a high degree of employment protection for standard employees, combined with a marked degree of flexibility to a large extent achieved through atypical contracts and an extensive underground economy. All these factors give rise to labour market segmentation related to the extreme fragmentation of the social security system and evident differences in employment protection.

As already mentioned, one of the structural weaknesses of the employment regime in Italy is the low integration of women into paid work. Over the past few decades, Italian women have greatly improved their educational attainment, and their labour market ambitions have increased accordingly. Together with the increase in education, the employment rate of women, especially mothers, increased to a significant extent in the decade before the crisis. However, gender gaps in employment rates remain amongst the highest in the EU272. Thus, women are not fully integrated into the labour market or remain in its margins, especially in Southern Italy ${ }^{3}$. In general, women suffer significant disadvantages (ranking 69th out of 142 overall), being penalized above all by the economic participation and opportunity category (114th) (World Economic Forum 2014). Italy lags behind in women's access to the labour market, remuneration, career advancement, promotion to positions of leadership and new business initiatives.

3 This is mirrored in the uneven spread of the male breadwinner model across Italian regions: in the centre-north an increasing number of couples with children have both partners in employment (but with a high share of mothers in part-time employment), while in the Mezzogiorno the male breadwinner model continues to prevail. 
in gaining access to jobs with adequate rights and social security provisions. Notwithstanding the advances achieved before the crisis, the economic participation rate of women is still considerably lower than that of men in Italy. This is explained by the familistic welfare model.

As in other Mediterranean countries, in Italy the family plays a central role in the provision of care and assistance to its members. Families are expected to support their members when they are in need of some kind of assistance, without intervention by the state. Accordingly, family policies are underdeveloped in comparison with those of other EU countries. In particular, a lack of affordable childcare services (for children aged under 3) restrains the female labour supply, especially in southern regions. Moreover, regional differences in the provision of nurseries by municipalities are very marked: the percentage of small children attending nurseries ranges from 3.6\% (in Calabria, in the South) to 27.3\% (in Emilia-Romagna, in the North) (Istat, 2014c). Moreover, income maintenance systems are inadequate, especially for people employed in atypical jobs, and they are fragmented ${ }^{4}$. These features are mirrored in a very low share of social expenditure relative to family and children, housing and social exclusion, and a high risk of poverty after social transfers. Recent research has confirmed the resilience of the familistic welfare model, despite the efforts made in the years before the crisis to overcome some of its major weaknesses (Ascoli and Pavolini, eds. 2015; Leon and Migliavacca, 2013).

The family-employment system is based on rather traditional gender roles: men are employed full time in secure jobs throughout their working lives, and are mainly responsible for earning enough for the economic wellbeing of the whole family; women have responsibility for family caring and domestic work. Although the reality is more diversified than this stylised model, this was the model around which labour market policies and personnel management practices were constructed and implemented. In short, the male breadwinner model of the family remains dominant. This explains, on the one hand, the high share of inactive mothers (especially in Southern Italy) and, on the other hand, the pervasive discrimination against maternity (Valentini, 2012) reflected in gender inequalities in the labour market, and also mirrored in a much higher female unemployment rate and a higher share of women in precarious jobs.

$4 \quad$ Tito Boeri (2012) has provided an estimate of the total number of people currently employed that are not covered by any form of benefit in the event of job loss. Out of a total 23 million people in employment, almost 10 million workers are excluded (56.8\%). Employees on openended contracts are the group with the highest coverage $(89.5 \%)$, followed by employees with fixed-term contracts (61.9\%), apprentices (21.1\%) and employer-coordinated freelances $(12.5 \%)$. Self-employed workers (accounting for almost one third of total employment) are excluded. In the most recent years, some changes have been introduced (with enactment of the Monti-Fornero reform in June 2012 and the Jobs Act in 2004-2015) in order to move towards a more universal unemployment benefit system. 
Although the non-symmetrical nature of work within families is gradually diminishing, the difficulties of balancing work and life can be seen with greater intensity when there are small children involved, as shown by the gap between the employment rates of men and women without children and with children (see tab. 1). While the employment rate increases for men when there are children, it decreases for women. As a result, the gap by sex in the employment rate is much higher when there are small children; and this implies that a significant number of women leave the labour market when they become mothers. However, there are large differences between the Centre-North (recording rates close to the EU27 average) and the Mezzogiorno (recording very low employment rates for mothers).

Table 1

Employment rate (25-49) by sex and presence of children in Italy and EU27, 2008 and 2014

\begin{tabular}{lccccccc}
\hline & \multicolumn{3}{c}{ 2008 EU27 } & 2014 EU & \\
\cline { 2 - 7 } & $\mathbf{M}$ & $\mathbf{F}$ & gap & $\mathbf{M}$ & $\mathbf{F}$ & gap \\
\hline Total & 87.4 & 72.6 & -14.8 & 83.4 & 71.9 & -11.5 \\
No children & 83.8 & 79.8 & -4.0 & 78.5 & 77.0 & -1.5 \\
1 child & 89.9 & 72.8 & -17.1 & 86.7 & 72.2 & -14.5 \\
2 children & 92.5 & 68.6 & -23.9 & 90.0 & 70.6 & -19.4 \\
3 children or + & 87.3 & 54.5 & -32.8 & 85.5 & 55.4 & -30.1 \\
\hline & & $\mathbf{2 0 0 8}$ Italy & & & $\mathbf{2 0 1 4}$ Italy & \\
\cline { 2 - 7 } & $\mathbf{M}$ & $\mathbf{F}$ & gap & $\mathbf{M}$ & $\mathbf{F}$ & gap \\
\hline Total & 86.7 & 61.2 & -25.5 & 77.5 & 57.7 & -19.8 \\
No children & 82.3 & 68.8 & -13.5 & 71.5 & 61.9 & -9.6 \\
1 child & 89.8 & 61.1 & -28.7 & 81.4 & 58.6 & -22.8 \\
2 children & 92.5 & 54.1 & -38.4 & 86.2 & 54.2 & -32.0 \\
3 children or + & 87.9 & 41.7 & -46.2 & 81.6 & 40.7 & -40.9 \\
\hline
\end{tabular}

Source: Eurostat, online codes: [lfsa_eppga], [lfsa_eppgai].

Table 2

Part-time employment and involuntary part-time for women aged 25-49, 2004, 2008 and $2014(\%)$

\begin{tabular}{|c|c|c|c|c|c|c|}
\hline & \multicolumn{3}{|c|}{ PT as \% of total employment } & \multicolumn{3}{|c|}{ Involuntary PT as \% of total PT } \\
\hline & 2004 & 2008 & 2014 & 2004 & 2008 & 2014 \\
\hline EU27 & 28.3 & 28.8 & 30.4 & 17.4 & 23.2 & 27.3 \\
\hline Italy & 25.9 & 29.3 & 34.4 & 31.1 & 37.2 & 59.9 \\
\hline
\end{tabular}

Source: Eurostat, online codes: [lfsa_eppga], [lfsa_eppgai]. 
An ad hoc national survey on female inactivity has shown that $46 \%$ of women who are inactive left work because of reconciliation problems (Isfol, 2010: 53). Administrative data (INPS) show that $25 \%$ of women who gave birth in 2009 were not back to work three years later (Mundo, 2012, in EP, 2014: 26). Finally, the Istat sample survey on births and mothers has shown that new mothers are facing increasing difficulties in returning to their jobs after motherhood during the crisis (Istat, 2012c, 2014a). Inactivity due to reconciliation problems is certainly very high in Italy, though with differences across the country. Whilst in the Mezzogiorno a large number of women in their prime age abandon active life when they become mothers (and some when they get married), in the CentreNorth an increasing number move to part-time.

In Italy, the percentage of women (aged 25-49) with a part-time job used to be far below the EU average (26\% in 2004), but it has increased rapidly over the last decade, up to $34.4 \%$ in 2014, higher than EU27 average (see tab. 2). But at present almost $60 \%$ of this part-time work is «involuntary»; moreover, the share of involuntary part-time almost doubled between 2004 and 2013. And the most important reason was the lack of full-time jobs, followed by the lack of flexible working arrangements and the difficulties met by women in reconciling work and family commitments (Istat, 2011b; Villa, 2012).

To sum up, the weaknesses of the family-employment system and the inadequacy of family policies now catch young women in the intergenerational solidarity trap: because of the lack of adequate family policies and the context unfavourable to working mothers (and in general, to women with family responsibilities) they have to choose between the family (taking care of the children, the elderly, frail family members) and employment. The outcome is the combination of very low female employment rates with very low fertility rates (Villa, 2012). It is within this scenario that one must assess the gendered impact of austerity policies.

\section{The financial and economic crisis and subsequent austerity policy}

We can take for granted that in Europe since 2010 there has been a decisive shift from fiscal stimulus to fiscal consolidation policies or austerity, after the remarkable deployment of various fiscal supports to countervail the global financial and economic crisis that exploded in 2008-09. Italy as a country of the Eurozone participates in the economic debate on the causes of and remedies for the slowdown. But it also takes a significant part in the unkept promises of austerity.

In the first phase of the global economic crisis (2008-2009), most governments introduced fiscal stimulus programmes; contrary to other countries, Italy implemented no expansionary fiscal measures to counteract the effects of the recession. The weakness of the public budget made it difficult to counteract those effects with an 
expansionary fiscal policy ${ }^{5}$. Nonetheless, the collapse of GDP inflated the debt/GDP ratio, which increased by 13 percentage points (from 103 in 2007 to 116 in 2009).

The sovereign debt crisis, which culminated in July 2011 with a sharp increase in the interest rates on Italian government bonds, forced the pursuit of fiscal consolidation. Three austerity packages were approved over a short period of time (Simonazzi, 2015a) ${ }^{6}$. Budgetary measures (tax increases and spending cuts), sale of public assets, and structural reforms (labour, pensions, liberalization of strategic sectors) were announced, implemented, and amended by the four governments alternating in office during the crisis.

Since 2010, the governments in office have considered and enacted all the various austerity strategies identified by Ortiz and Cummins (2013: 13-17) in their review of adjustment measures in the age of austerity ${ }^{7}$. In short, it was decided to prioritise fiscal balances over employment, on the hypothesis that further labour market reforms, by reducing the residual rigidities (on individual and collective dismissals, and collective bargaining on wages), would help to foster employment growth. The principal austerity measures implemented so far can be grouped under six main headings.

i) Cuts in national government transfers to local governments. Drastic reductions were made to financial transfers to regions and local authorities. Because local governments are responsible for social services, they are most likely to produce a lower amount of services. And women are likely to substitute for the public provision of these services by providing unpaid work within the household. A recent report on the provision of childcare services has revealed that between 2004 and 2011 there was an overall increase in current expenditure on nurseries and in the number of children enrolled at public nurseries or private nurseries financed by the municipalities. But in 2011 and 2012 there was a decrease in both enrolments and the contributions paid by municipalities for private nurseries (Istat, 2014c).

ii) Cuts in social policy expenditure. The national fund for social policy was decimated, the fund for non self-sufficiency cancelled (to name only two actions). In short, the embryonic and underdeveloped national social policy was almost completely dismantled, once again delegating to the family (and consequently to women) the care of its frail members (Simonazzi, 2015a, 2015b). rage of $3.4 \%$ for the main advanced economies, and it was achieved mostly by changing the composition of the budget, leaving the balance unchanged (Simonazzi, 2015a). The first two were presented by the Berlusconi centre-right government in August and November 2011. The last and tightest one was approved in December 2011 by the coalition government led by Mario Monti. In 2013 austerity policy was continued, though it was less restrictive than in the previous years. 
iii) Wage freeze and cuts in jobs in the public sector. Spending cuts consisted also in reductions in the compensation of employees in general government (in particular, in health and education). The compensation of public employees (in terms of per cent of GDP) had been falling since 2009. Two main strategies have been envisaged: first, very tight limits on hiring (no more than $20 \%$ of people exiting the public sector) that have already resulted in a significant fall in employment (see tab. 3); second, the freeze on wage increases and collective wage bargaining (Banca d'Italia, 2014: 108). And both strategies are still in force, so that further delayed effects are expected. This entails a decrease in opportunities for the young cohorts with high educations in general, and for women in particular. To be pointed out is that, in Italy, the growth of female employment recorded after the mid-1990s was driven by the services sector, which includes the activities of the public administration. This sector played a major role in raising female employment, so that by the mid-1990s women constituted the majority of civil servants (Tibaldi, 2009).

Table 3

Employees in the public sector in Italy by sex, 2001, 2007 and 2013 (no. and \% change)

\begin{tabular}{lccccc}
\hline & $\mathbf{2 0 0 1}$ & $\mathbf{2 0 0 6}$ & $\mathbf{2 0 1 3}$ & \% change 2001-2006 & \% change 2006-2013 \\
\hline M & $1,727,921$ & $1,616,366$ & $1,428,619$ & -6.5 & -11.6 \\
F & $1,776,243$ & $1,854,267$ & $1,804,335$ & +4.4 & -2.7 \\
MF & $3,504,164$ & $3,470,633$ & $3,232,954$ & -1.0 & -6.8 \\
\hline
\end{tabular}

Source: Ragioneria Generale dello Stato, Conto annuale. http://www.contoannuale.tesoro.it/

It should be stressed that the public sector not only represents a high proportion of women's employment in Italy but is also considered to be the best employer for working mothers in terms of flexible work arrangements, as in other advanced countries where the emancipation process has historically seen increasing female educational attainment levels, an expansion of female employment in the public sector, and a progressive move towards the dual-earner model (Rubery, 2013).

iv) Increasing consumption taxes on basic products. VAT was increased to $21 \%$ in 2011 and to $22 \%$ in 2013. Basic products are disproportionately consumed by low-income and poor households; therefore, the increase in indirect taxation has contributed to further reducing households' disposable income and to increasing income inequality. As pointed out in the literature on gender budgeting (Stotsky, 2006: 23; Grown and Valodia, 2010), indirect taxes may contain implicit gender biases in several forms. Given 
that indirect taxes affect the price of private goods and services, they not only reduce households' purchasing power but also interact with demand for goods and services, with inherent gender biases. These indirect effects on gender inequalities have not been taken into consideration by policy makers in Italy. In years of severe recession, the protracted decline in disposable income has affected consumers' plans, with a shift from purchasing certain services in the market to home production, mainly through unpaid female work.

v) Pension reform. A new reform was precipitously enacted at the end of 2011 to respond to the urgent need to reduce public expenditure and appease financial markets (and the EU). The minimum retirement age was increased to 66 for all, men and women, by January 2018 (and a gradual rise up to 70 years is planned after 2018), with pension benefits strictly linked to contributions paid. Advocated in the name of gender equality and financial sustainability, the law cancelled the more favourable conditions for women which had been some sort of compensation for their unpaid care-work. However, no provision has been envisaged to re-balance the huge income disparities between retired men and women. The average pension of a woman is now around 69\% of a man's (Bettio et al., 2013). The pension gap may soon become dramatic when the amount of the pension is calculated exclusively on the basis of the contributions paid, given the over-representation of women in part-time and precarious jobs, and the many interruptions in their work lives. Moreover, the increase in retirement age makes reconciliation still more difficult, especially considering the simultaneous cuts in social expenditure and transfers to local governments. It should be recalled that in Italy grandparental childcare tends to be a substitute for formal childcare, especially for low educated mothers and those living in the CentreNorth (Arpino, Pronzato and Tavares, 2014). Thus, the increase in women's retirement age not compensated by a concomitant increase in public childcare services may reduce the labour supply of mothers of small children.

vi) Labour market reforms. The labour market has been one of the preferential areas of «structural reforms» in Italy since the late 1990s. The idea inspiring policy makers - following the recommendations put forward by the European Commission - has been that the labour market must be made 'more flexible', i.e. 'more market friendly', in order to enhance labour market adjustments to shocks (Zenezini, 2014). The four governments in office through the crisis have continued the tradition: they have all made announcements, enactments and amendments for a new labour market reform. An important and complex law was approved by the Parliament on June 2012 (the so called Monti-Fornero reform), after months of discussions and shilly-shallying. The ambitious aim of this reform was to shake 
up the labour market, and it was driven by three main objectives: (i) clamping down on certain widespread abuses of what are generally referred to as «precarious» work contracts (i.e. increasing the costs for firms); (ii) liberalizing individual lay-offs for economic reasons, partly compensated by (iii) introducing a more universal system of unemployment benefits. After only a year and a half, a new reform (the so called Jobs Act) was initiated by the new Renzi government. The enabling bill for the reform of the labour market was passed at the end of 2014. The first two enacting decrees, which took effect in March 2015, reinforce some of the principles underlying the measures introduced in 2012. They further extend the pool of potential recipients of unemployment benefits and amend the legislation on individual dismissals, not only making the consequences of any firing decisions more predictable but also introducing a new contractual arrangement (to be applied only to new hirings) associated with a lower cost of dismissal. Despite differences in assumptions and goals, all the changes implemented have been inspired by the idea that increasing labour market flexibility and weakening collective bargaining is good for growth. Gender equality, an issue which has never been high on the political agenda in Italy, has been set aside despite increasing attention by the media and international organisations $(\mathrm{EC}, \mathrm{OECD}, \mathrm{IMF})^{8}$ to the very low integration of women in the labour market. The only effort made in this regard has relied on a series of employment subsidies (tax deductions and/or reductions in social contributions for employers), despite doubts on their efficacy in creating additional jobs for women.

Fiscal consolidation has resulted in a contraction of economic activity, lower aggregate demand, job destruction and higher unemployment. Italy under stronger austerity has achieved neither fiscal consolidation (paradoxically, despite continuous fiscal austerity, the loss in output has swollen the debt/GDP ratio to $132.6 \%$ in 2013 , from $116 \%$ in 2009) nor faster recovery, but rather lower shock absorption, worse recovery performance and higher unemployment.

After seven years of stagnation, Italy is now undertaking broad-based and ambitious reforms to boost growth by taking advantage of synergies among policies. According to OECD's economic survey (February 2015) «labour market reform is essential to give companies the flexibility to innovate, restructure, and boost productivity». The "Jobs Act, adopted in December 2014, aims to rationalise employment protection, expand active labour market policies, make social

To mention just one recent example, Christine Lagarde (head of the IMF) in an interview (Corriere della Sera, 4.4.14) has said that Italy has done very little to promote the role of women in the workplace. She added «a change of strategy is needed»: not only would it help Italy to advance socially but the additional income generated would help the country emerge from economic stagnation. 
protection more effective and boost women's participation in the workforce». The focus is again on the new labour market reform (so called Jobs Act) despite the evidence that the range of impacts of product market reforms are notably larger than those of labour market reforms (IMF, 2013; Zenezini, 2014).

\section{Labour market impact of the crisis on women and men}

The austerity policy implemented in Italy has deteriorated the macroeconomic conditions, leading the country into a very long period of recession, with strong negative impacts on the labour market. Employment conditions have dramatically worsened for all: women and men, nationals and foreigners, young and prime-age workers, people living in the Centre-North and in the South, but with very different impacts in terms of job loss (due to labour market segmentation and segregation) and outcomes in terms of income loss (because of the lack of universal relief measures).

Table 4 shows the evolution of the main labour market variables by gender between 2008 and 2014. The number of persons employed fell in all parts of the country (but especially in the South) and all sectors, but most of all in construction and general government. In 2014 employment declined also in the private service sector, where it had continued to grow during the previous three years. The number of people in employment declined by $7.9 \%$ for men, but only slightly for women. Employment rates declined for all population subgroups, but was more pronounced among men (from $70.3 \%$ to $64.7 \%$ ) and especially younger men (in the 15-34 age group). For the population aged 55-64, by contrast, the employment rate rose, especially for older women, owing in part to the pension reform enacted in 2011.

In the crisis years (2008-2014), the number of persons active in the labour market diminished among men and increased among women. Among men, the decline was sharpest among those aged 15-34. There was a decline in participation among women in that age group as well, but this was more than offset by an increase in the older age groups (women over 50). Data on female labour supply show the coexistence of two opposing trends. On one hand, women in their prime age increased their participation rate throughout the crisis, entering the labour market to sustain family income. On the other hand, there was an increase in discouragement (among younger women, especially in the South) ${ }^{9}$. living in couples with or without children, using the EU-SILC 2011 micro data for Spain and Italy. The analysis carried out shows a strong countercyclical added-worker effect for women in response to transitory shocks in partner's earnings, in contrast with a pro-cyclical discouraged-worker effect for men. However, for women the added-worker effect prevails in Spain while the discouraged worker effect dominates in Italy. 
Table 4

Main labour market indicators by sex, 2008 and 2014 ('000 and \%)

\begin{tabular}{lrrrr}
\hline & $\mathbf{2 0 0 8}$ & $\mathbf{2 0 1 4}$ & Absolute change & \% change \\
\hline Employed (15-64) ('000) & & & & \\
M & 14,063 & 12,945 & $-1,118$ & -7.9 \\
F & 9,341 & 9,334 & -7 & -0.1 \\
Employment rate (15-64) (\%) & & & & \\
M & 70.3 & 64.7 & -5.6 & \\
F & 47.2 & 46.8 & -0.4 & \\
gender gap & 23.1 & 17.9 & & \\
Unemployed ('000) & & & & \\
M & 821 & 1,742 & 938.8 \\
F & 872 & 1,494 & 633 & \\
Unemployment rate (\%) & & & & \\
M & 5.5 & 11.9 & 6.4 & \\
F & 8.5 & 13.8 & 5.3 & \\
gender gap & -3.0 & -1.9 & & \\
Potential additional labour force ('000) & & & & \\
M & 983 & 1,390 & 421 & \\
F & 1,805 & 2,067 & 279 & \\
Non-participation rate (\%) & & & & \\
M & 11.0 & 19.3 & 8.3 & \\
F & 21.6 & 27.3 & 5.7 & \\
gender gap & -10.6 & -8.0 & & \\
\hline
\end{tabular}

Source: Istat, Labour Force Survey, in: Istat (2015, Chapter 4: 153).

The contraction of the labour force can be ascribed largely to the increase in the number of persons who, while wanting and available to work, said they had stopped actively seeking employment because there were no job openings. This increase (particularly large in 2013), brought the number of these discouraged workers to 1.4 million, 400,000 more than in 2008 (Banca d'Italia 2014: 84). Somehow surprisingly, this discouragement effect was much larger among men than among women. Despite the contraction of the labour force due to discouragement, the sharp decline in employment resulted in an increase in the number of unemployed persons, which rose to 1.7 million for men and 1.5 million for women in 2014. The unemployment rate rose to $11.9 \%$ for men and $13.8 \%$ for women. The increase was very pronounced among the young, men and women.

The unemployment rate in the case of Italy does not fully express the distress caused by the lack of jobs. Two supplementary indicators can be used. The first, called the 'potential additional labour force' (PAF), is given by the sum of two groups: «persons seeking work but not immediately available» and «persons 
available for work but not seeking it». Persons in the PAF are not part of the standard labour force, which encompasses only employed and unemployed people; however, they have a stronger attachment to the labour market than other economically inactive persons. As expected, there are more women than men in this cluster, and an increase was recorded during the crisis; but this rise was relatively small among women $(+15.6 \%)$ and very large among men $(+43.4 \%)$ (see tab. 4). The second indicator, «non-participation rate», adds to the unemployed persons also part of the potential labour force (those who are inactive because they have not looked for a job in the past 4 weeks but are willing to work). Also this indicator records an increase during the crisis greater for men than for women $(+8.3$ and +5.7 percentage points). However, the overall disadvantage for women remains substantial with respect to men (27.3\% and $19.3 \%$, respectively).

Gender gaps in labour market indicators are still large in Italy; they have been narrowing in recent years, but due more to the worsening of men's working conditions than to any progress in those of women. The present economic and fiscal crisis has so far affected less the quantity of female jobs than their quality.

In terms of quantity, the crisis has put a halt to the positive (but not exceptional) trend recorded for female employment in the decade preceding the Great Recession. At the national level, the female employment rate reached its maximum of $47.2 \%$ in 2008 (well below the $60 \%$ target for 2010), and went back to $46.5 \%$ in 2013 . As a result of the gender segregation in the labour market (i.e. concentration of female employment in care and health, education, retail and other services), job destruction has to date not been so dramatic for women as for men. In some occupations, in particular homecare for the elderly, there has been an increase (but for female migrants) ${ }^{10}$. Though employment has decreased globally more for men due to labour market segregation, in the near future young women will be the most adversely affected by austerity measures because public employment is declining very fast and public services are disappearing or deteriorating.

As regards the quality of female employment, the crisis has aggravated a situation that was already quite critical by accentuating several structural weaknesses. First, despite the dramatic increase in male unemployment, unemployment rates are systematically higher for women, signalling their greater difficulties in entering or re-entering active life. Second, reconciling work and family remains overwhelmingly a women's responsibility: the supply of public childcare services (for children aged under 3 ) remains inadequate ${ }^{11}$ and it is not expected to increase in the near future due to budget cuts for local municipalities; there is a chronic lack of services for the elderly, which is overcome within the

10 Trends in female employment by nationality suggest that female migrants continue to be recruited by Italian families in order to allow a certain number of Italian women to stay in employment, thus overcoming the lack of gender equality policies.

11 The average coverage rate is $13.5 \%$, well below the $33 \%$ Barcelona target, with wide variability across local municipalities (EP, 2014: 27) 
family both/either with unpaid work by female relatives and/or the help of female migrants; flexible working arrangements are rarely made available because of a lack of incentives for employers and a lack of funds to implement plans supported by the law (EP 2014: 28); finally, there has been little change in men's role within the family over time (Verashchagina and Capparucci, 2013: 251). Third, women remain under-represented in standard employment, despite its larger decrease among men, and they are over-represented in precarious employment ${ }^{12}$, despite its larger decrease among women (Istat, 2014: 89). Last, but not least, the gender pay gap (GPG, measured in unadjusted form) shows a steady increase over the crisis, contrary to the general tendency observed in the EU27. This has been explained with the expansion of low-pay female jobs (in care services) and the increasing precariousness of young women with high educations (Bettio, 2013).

\section{Changing family roles in times of austerity}

The family-employment system based on traditional gender roles (i.e. the male breadwinner household) that in the past limited the emancipation of women through paid work has proved unable to absorb the disruptive effects of a major crisis. The fall in total employment, the contraction in family incomes, and the lack of a universal safety net have increased poverty among lower income families (characterised by inactive women) and impoverished middle class families (with large numbers of women employed in part-time jobs). The share of households in absolute poverty doubled between 2007 and 2012 (from 4.1 to $8.0 \%$, and accelerated since 2011); families with children, single parents and jobless households have recorded the sharpest increases (Istat, 2014: 174) ${ }^{13}$. With widespread male unemployment, previously inactive women have been pushed into the labour market to supplement or make up for the loss of the male's income. Thus, during the crisis the 'discouraged worker effect' has prevailed among men (especially among the younger age groups), while the 'added worker effect' has prevailed among women in Italy (especially among prime age women in Mezzogiorno to compensate for their partner's unemployment) , as in other Southern countries (COM 2014). The willingness of women to increase their labour supply during the crisis (and the constraints they face due to traditional gender roles) is confirmed by the increasing share of involuntary part-time (Villa, 2013). In 2014, female part-time employment was 32.1\% (recording an

\footnotetext{
12

The over-representation of young women on contractual arrangements with limited or no protection implies that they cannot rely on the provisions granted to standard employees in the case of maternity (Villa, 2012).

13 Increases in the incidence of absolute poverty and material deprivation have been registered throughout Italy, though disproportionately in the South.
} 
increase of 4.4 percentage points in five years); at the same time, the share of involuntary part-time among women rocketed to $60.4 \%$ (from $38 \%$ in 2008$)^{14}$.

\section{Competitiveness, social inclusion and gender equality}

On the one hand, the Italian family-employment system has been unable to absorb or to dampen the effects of the crisis. On the other hand, Italy is loosing ground in any comparative evaluation of economic policies to enhance labour market participation, employment and social inclusion. The two are closely intertwined: the best way to secure social inclusion is to ensure gainful employment to a larger share of the population, firstly women. And social inclusion partakes of European competitiveness indicators ${ }^{15}$.

A recent comparative assessment of 28 European countries (World Economic Forum, 2014) shows that Italy is dramatically weak in terms of inclusive growth ${ }^{16}$, one of the three sub-indexes of the Europe 2020 Competitiveness Index. This 'inclusive growth' sub-index captures the extent to which every member of society can contribute to and benefit from Europe's growth and development. This is captured through two pillars, one measuring the labour market and employment conditions, the other measuring social inclusion at large. To a large extent the inclusive growth sub-index reflects the capacity of an economy to provide security of employment rather than security of jobs.

The results for 2014 show that, despite the stability of Italy's global competitiveness index ( 21 out of 28 in 2012 and 2014), the country ranks 28 out of 28 for labour market and 21 out of 28 for social inclusion, dropping positions since 2010. In other words, whilst Italy has some strengths in its enterprise environment, its competitiveness is hindered by labour market conditions $\left(28^{\text {th }}\right)$ and social inclusion conditions $\left(21^{\text {st }}\right)$. The former case deprives wide segments of the population of gainful employment (women and youths); the latter case shows that the best performance concerns the accessibility of healthcare services $\left(19^{\text {th }}\right)$ rather than social mobility $\left(24^{\text {th }}\right)$ or governmental effectiveness in reducing poverty and inequality $\left(25^{\text {th }}\right)$.

If inclusive growth is an important part of future European competitiveness, Italy drops positions, going in the direction of exclusive rather than inclusive growth. It especially lags behind in women's access to the labour market,

14 The decline in labour input involved a significant shift from full-time to part-time positions. During the period 2008-2014, full-time work declined substantially for both men and women, while part-time work increased, especially for women (Istat 2015: 161-164). This micro level must consider also the macro perspective; for instance, the two way relationship between gender inequality and macroeconomic outcomes is examined in Seguino (2012).

16 Crisis and austerity measures have emphasized the predominance of public finance concerns over inclusive growth especially for member states performing below the average in terms of poverty and social inclusion. 
remuneration, career advancement, promotion to positions of leadership and new business initiatives. In 2014 the country was among the worst performers in the Global Gender Gap Index (ranking 69th out of 142 overall), being penalized above all by the economic participation and opportunity category (114 $\left.{ }^{\text {th }}\right)$ (World Economic Forum 2014).

\section{Conclusions}

Italy is an interesting case with which to verify the impact of fiscal consolidation policies because of the gendered nature of the country's family-employment system. The severe economic crisis of 2008-2009 followed by austerity policies has affected women and men differently. Although gender gaps in labour market indicators are still large, they have been narrowing recently; but this has been due to the worsening of men's working conditions, not to any progress in those of women.

Today it is the intertwined effects of long-standing imbalances and the shifts to austerity policies that have created new differential impacts on women and men. On the one hand, the inadequacy of the Italian family-employment system in absorbing disruptive effects of the crisis has locked young women in a new intergenerational solidarity trap, family versus employment. On the other hand, one of the main effects of the crisis has been on the quality of female jobs, enhancing structural weaknesses of the Italian labour market. Both are examples of the exclusive rather than inclusive growth for which Italy, in comparison with other countries, keeps loosing ground.

\section{References}

Arpino, Bruno; Pronzato, Chiara D.; Tavares, Lara P. (2014), «The effect of grandparental support on mothers' labour market participation: an instrumental variable approach», European Journal of Population 30(4), 369-390.

Ascoli, Ugo; Pavolini, Emmanuele (eds.) (2015), The Italian Welfare State in a European Perspective, Bristol, Polity Press.

Banca d'Italia (2014), Annual Report, Rome, 30 May, [online] available in https:// www.ban caditalia.it/pubblicazioni/relazione-annuale/2013/index.html [retrived on 23/01/2015].

Bettio, Francesca (2013), «Perché in Italia si riapre il gender pay gap», 30 May, www.ingenere.it. [retrived on 23/01/2015].

Bettio, Francesca; Tinios, Platon; Betti, Gianni (2013), The gender gap in pensions in the EU, Luxembourg, Publications Office of the European Union.

Boeri, Tito (2012), «Le tasse, il lavoro e la crescita», Senato della Repubblica, 29 February 2012.

EP (2014), The Policy on Gender Equality in Italy, Brussels, European Parliament, Policy Department C: Citizens' Rights and Constitutional Affairs, FEMM Committee. 
Gálvez-Muñoz, Lina; Rodríguez-Modroño, Paula; Addabbo, Tindara (2013), «The impact of European Union austerity policy on women's work in Southern Europe», Department of Economics Marco Biagi, DEMB Working Paper Series, October, 18.

Grown, Caren; Imraan, Valodia (eds.) (2010), Taxation and Gender Equity. A Comparative Analysis of Direct and Indirect Taxes in Developing and Developed Countries, Oxon and New York, Routledge.

IMF (2013), «Fiscal Consolidation in the Euro Area: How Much Can Structural Reforms Ease the Pain?», Working Paper, October, [online] available in http://www.imf.org/ external/pubs/ft/wp/2013/wp13211.pdf [retrived on 14/02/2015].

Isfol (2010), Perché non lavori? I risultati di un'indagine Isfol sulla partecipazione femminile al mercato del lavoro (a cura di Roberta Pistagni), I libri FSE,Roma, Isfol.

Istat (2011b), «Il part-time involontario», in Rapporto annuale 2010, Roma, Istat, 152.

Istat (2012c), «Maternità e partecipazione femminile al mercato del lavoro», in Rapporto annuale 2012, Roma, Istat, 120-121.

Istat (2014a), Avere figli in Italia negli anni 2000, Roma, Istat.

Istat (2014b), Rapporto Annuale 2014, Roma, Istat.

Istat (2014c), «L'offerta comunale di asili nido e altri servizi socio-educativi per la prima infanzia», Statistiche Report 29 luglio.

Istat (2015), Rapporto Annuale 2015, Roma, Istat.

Leon, Margarita; Leon, Migliavacca, (2013), «Italy and Spain: still the case of familistic Welfare Models?», Population Review 52(1), 25-42.

Ortiz, Isabel; Cummins, Matthew (2013), «The Age of Austerity: A Review of Public Expenditures and Adjustment Measures in 181 Countries «, Initiative for Policy Dialogue and the South Centre, Working Paper, March, [online] available in http://policydialogue.org/files/publications/Age of Austerity Ortiz and Cummins.pdf [retrived on $14 / 03 / 2015]$.

Perrons, Diane (2015), "Gender equality in times of inequality, crisis and austerity: towards gender-sensitive macroeconomic policies«, in Francesca Bettio; Silvia Sansonetti (eds.), Visions for Gender Equality, Luxembourg, Publication Office of the European Union.

Rodrik, Dani (1998), «Why do more open economies have bigger governments», Journal of Political Economy 106(5), 997-1032.

Rodrik, Dani (2011), The Globalization Paradox: Democracy and the Future of the World Economy, London, W.W. Norton.

Rubery, Jill (2015), «Austerity and the future for gender equality in Europe», ILR Review August, 715-741.

Rubery, Jill (2013), «Public sector adjustment and the threat to gender equality«, in Daniel Vaughan-Whitehead (ed.), The Public Sector Shock. The Impact of Policy Retrenchment in Europe, Geneva, Switzerland, ILO, 23-43.

Seguino, Stephanie (2012), «From micro-level gender relations to macro economy and back again. Theory and policy», in Deborah Figart; Tonia Warnecke (eds.), Handbook of Research on Gender and Economic Life, Northhampton, MA, Cheltenham, 325-344.

Simonazzi, Annamaria (2015a), «Italy: Continuity and Change in Welfare State Retrenchment», in Daniel Vaugham -Whitehead (ed.), The European Social Model in Crisis. Is Europe losing its soul?, E. Elgar, Cheltenham, 339-385.

Simonazzi, Annamaria (2015b), «Italy's long stagnation», in Steffen Lehndorff (ed.) Divisive Integration-The Triumph of Failed Ideas in Europe, Brussels, European Trade Union Institute-ETUI.

Stotsky, Janet (2006), «Gender Budgeting», IMF Working Paper, No. 06/232. 
Tibaldi, Mauro (2009), «L'occupazione femminile nella Pubblica amministrazione: un'analisi dei dati della Ragioneria Generale dello Stato«, Contributi Istat 3.

Valentini, Chiara (2012), O I figli o il lavoro, Milano, Feltrinelli.

Verashchagina, Alina; Capparucci, Marina (2013), «Living through the crisis in Italy», in Maria Karamessini; Jill Rubery (eds.), Women and Austerity, London, Routledge.

Villa, Paola (2010), «La crescita dell'occupazione femminile: la polarizzazione tra stabilità e precarietà», Lavoro e Diritto 3, 343-358.

Villa, Paola (2012), «Club Med», European Women's Voice, Spring, 16-18.

Villa, Paola (2013), «Il lavoro part-time in Italia ai tempi della crisi», $1^{\text {st }}$ October, www.ingenere.it. [retrived on 14/03/2015]

World Economic Forum (2014a), The Global Gender Gap Index. «Italy», [online] available in http://reports.weforum.org/global-gender-gap-report-2014/economies/\#eco nomy=ITA. [retrived on 14/06/2015]

World Economic Forum (2014b), The Europe 2020 Competitiveness Report: Building a More Competitive Europe, Geneva.

Zenezini, Maurizio (2014), «Riforme economiche e crescita: una nota critica», Economia $\mathcal{E}$ Lavoro 3, 99-128.

Maria Luigia Segnana. Full professor of economics, Department of Economics and Management, University of Trento.

E-mail address: marialuigia.segnana@unitn.it

Paola Villa. Full professor of applied economics, Department of Economics and Management (DEM), University of Trento.

Postal address: DEM, University of Trento, Via Inama 5, 38100 Trento (Italy).

E-mail address: paola.villa@unitn.it

Artigo recebido em 9 de fevereiro de 2015 e aceite para publicação em 29 de julho de 2015. 